\title{
UNIVERSITYOF
}

FORWARD

THINKING

WESTMINSTER用

WestminsterResearch

http://www.westminster.ac.uk/westminsterresearch

Heritage as theatre: re-conceptualizing heritage-making in urban China

Wang, C.

This is a copy of the accepted author manuscript of the following article: Wang, C. (2017) Heritage as theatre: re-conceptualizing heritage-making in urban China, China Information. 31 (2), pp. 195-215. The final definitive version is available from the publisher Sage at:

https://dx.doi.org/10.1177/0920203X17709916

(C) The Author(s) 2017

The WestminsterResearch online digital archive at the University of Westminster aims to make the research output of the University available to a wider audience. Copyright and Moral Rights remain with the authors and/or copyright owners.

Whilst further distribution of specific materials from within this archive is forbidden, you may freely distribute the URL of WestminsterResearch: ((http://westminsterresearch.wmin.ac.uk/).

In case of abuse or copyright appearing without permission e-mail repository@westminster.ac.uk 
Author accepted manuscript

The final, definitive version of this paper will be published in China Information in 2017, published by SAGE Publishing, All rights reserved.

\section{Heritage as theatre: re-conceptualizing heritage-making in urban China}

\section{Cangbai Wang}

University of Westminster, UK

\section{Introduction}

Since China ratified UNESCO's World Heritage Convention in 1985, cultural heritage in China has become a booming industry and a key area of scholarly investigation from multiple disciplinary perspectives. The global regime of the world heritage industry is shaped by a universalistic conceptualization of cultural value derived from Euro-American cosmology and philosophy. Ironically, 'far from being incompatible with state interests, China incorporates UNESCO's universalism within its developmental interests of modernization and to legitimize its own claims to a millennial legacy of civilization'. Indeed, heritage has become a powerful state discourse of development and modernization in contemporary China. ${ }^{2}$ Evidence of this lies in how Chinese authorities at different levels have used heritage discourse as a tool to promote tourism for domestic and international consumption, ${ }^{3}$ to alleviate poverty in ethnic minority regions and integrate non-Han populations into dominant Chinese (Han) society ${ }^{4}$ and to civilize the rural population for the building of the New Socialist Countryside. ${ }^{5}$ More significantly, since the mid-1990s, heritage discourse has become an integral part of China's construction of a new sense of urban modernity. It has played an important role in urban regeneration and city branding in 
mega-cities, ${ }^{6}$ in 'urban scaling-up' and city marketing in small-and-medium cities, ${ }^{7}$ as well as urbanizing ethnic minority regions in Southwest China. ${ }^{8}$

The existing literature on China's cultural heritage and urbanization varies in terms of investigative focus and analytical perspective, but converges in pointing to the centrality of the state in defining and utilizing heritage. The nature of this state-led heritage-making is summarized aptly by Tim Oakes as 'a technology of government'" or 'heritage as improvement', ${ }^{10}$ strongly associated with the Foucauldian notion of 'governmentality', referring to the ways in which the government produces civilized citizens and social order through an ensemble of hegemonic knowledge sustained by institutions, procedures, analysis, calculations and so on. ${ }^{11}$ The central concern of this line of analysis is how heritage 'is instrumentalized as a vehicle for governmental power and what sorts of political rationalities its use in this way generates. ${ }^{12}$

While identifying an affinity between heritage-making and governmentality is helpful for enhancing our understanding of cultural heritage in general, what 'governmental power' means and how it is exercised in the Chinese context is far from clear. The 'heritage as improvement' argument to some extent conceptualizes modernity through a Western-originated view of development built upon historically and ideologically defined binaries of order and disorder, modernity and tradition, civilization and backwardness. Modernity is defined in close association with rationality, in contrast to irrationality, considered intrinsic to pre-modern and uncivilized societies. Citing Yi-Fu Tuan and Steven Hoelscher, Oakes has argued that there was a parallel between the ideal civilized Chinese city and the Disney Park, maintaining that 'the ideal city was more than anything a project of keeping chaos perpetually at bay'. ${ }^{13}$ 'Chinese 
officials, no less than Disney officials, both fear and deprecate the sort of uninhibited carnivalesque atmosphere so beloved of the critics of bourgeois order, notably Mikhail Bakhtin’. ${ }^{14}$

While 'keeping chaos at bay' might describe the situation and purpose of making heritage in some places, more and more research has, in contrast to Oakes' view, suggested that China's heritage-making does not lack a carnivalesque atmosphere. On the contrary, it has become a common practice for the Chinese government to build gigantic museums to promote 'a monumental vision of heritage', ${ }^{15}$ and to put on spectacular shows to act out local cultural heritage. ${ }^{16}$ In promoting its image of the modern city, it is now de rigeur for the Chinese government to revive and reinvent old customs and traditions, and/or invent new ones, ${ }^{17}$ and to resort to sensational audiovisual spectacles to invoke cultural imaginaries of desirable place identities. Among these, the most notable example is perhaps the 'impression series' directed by the famous Chinese film director Zhang Yimou and staged in the city of Yangshuo and Lijiang. Using cinematic skills, pyrotechnic and special effects, and incorporating the performances of singers, dancers and acrobats, the shows conjured up an image of a place desirable to both international and domestic spectators. ${ }^{18}$ Here, heritage is made not by the forces of political rationality but by the power of 'happy daydreaming', ${ }^{19} \mathrm{a}$ psycho-cultural process that could be described as a process of hypnotic-like enchantment or captivation of its audiences.

Historians and anthropologists have revealed the complex ways in which Asian and African societies negotiated processes of modernization, ${ }^{20}$ challenging the longstanding view that modernity is 'disenchanted' as a result of the 'modern' processes 
of rationalization, secularization, and bureaucratization..$^{21}$ As we are reminded by Michael Saler, 'modernity is as enchanted as it is disenchanted'.22 'Modernity is defined less by binaries arranged in an implicit hierarchy, or by the dialectical transformation of one term into its opposite, than by unresolved contradictions and oppositions, or antinomies: modernity is Janus-faced'. ${ }^{23}$ Drawing on Simon During, ${ }^{24}$ he further argued that 'magical assemblages', such as modern magic, works of avantgarde art, literature, the cinema, and 'show business', are modern forms of enchantment, things that 'delight one's reason and imagination without deluding them'. ${ }^{25}$

Following Saler's view of modernity and enchantment, this paper attempts to reconceptualize China's heritage-making by shifting the focus away from neat political rationalities to messy 'magical assemblages'. It suggests that disenchanted reason is not incompatible with enchanted imagination and wondrous spectacles. The Chinese government and cultural elites have turned China's urban space into an interiorized cultural imagination of the modern city by using not only rationalized governmentality but also, and sometimes more effectively, the power of spectacle, sensation and awe. Heritage is therefore as much 'a technique of enchantment' as 'a technique of government'. Here, performance is not merely 'the exterior representation of culture' as argued by some scholars. ${ }^{26}$ Instead, China's heritage industry is a 'theatre' in itself, a political-social-cultural complex in which the meaning of heritage is contested, fabricated and played out on a deliberately and specifically constructed stage.

\section{Heritage as theatre}


In his study of Balinese society, Clifford Geertz applied a cultural interpretation to ceremonies, rituals and symbols to analyze the social organization of Bali before it was colonized by the Dutch in $1906 .{ }^{27} \mathrm{He}$ found that rather than being ruled by tyranny or effective administration as conceptualized by standard Western political theories, Negara was a 'theatre state' governed by spectacles, ceremonies and the public dramatization of the ruling obsession of Balinese culture. As he famously argued:

It was a theatre state in which the kings and princes were the impresarios, the priests the directors, and the peasants the supporting cast, stage crew, and audience. The stupendous (ceremonies) ... were not means to political end: they were the ends themselves, they were what the state was for ... Power served pomp, not pomp power. 28

While Geertz's notion of 'theatre state' has been an inspiration to research on various subjects in different social and historical contexts, ${ }^{29}$ it has not yet been given adequate attention in the field of heritage studies. The value of a Geertzian perception for heritage studies, at least in the Chinese context, is its emphasis on the fundamental importance of a 'poetics of power' - indicating a notion of ruling through symbols, ceremonies and performance rather than administrative regulation - to state-led heritage-making. I am not saying that China is another 'theatre state' characterized by chaos and violence as seen in pre-colonial Bali, nor do I contend that China's cultural heritage-making is all about sustaining social hierarchies and privileges along the lines of the Balinese state. What I want to suggest here is the usefulness of an 
interpretative approach that sees culture as a set of texts or a series of public acts in which the state authorities release 'imaginative energies' by using various signs and symbols in specific social and historical contexts. It unearths in particular the crucial role of 'culture of spectacle' in the state-led construction of cultural heritage in various locales and at different scales. ${ }^{30} \mathrm{I}$ argue that in the conditions of "postsocialist' China characterised by the amalgamation of political power, market force and cultural identifications, dramatic museum representation, monumental architecture and expressive ceremonies are as vital as, if not more important than, laws, state policies, institutional regulations and certification of authenticity by cultural experts and the heritage authorities, in the making of cultural heritage. It is therefore essential to be analytically sensitive to meanings of the relevant myths, ceremonies and symbols in relation to the creation and transmission of heritage, to balance out the overwhelming emphasis on scientific/rational debates in the existing scholarship on cultural heritage.

This paper conceptualizes China's urban heritage industry as a 'theatre'. It pays particular attention to the role of cultural spectacles in constructing and performing heritage, and how China's heritage industry is becoming part of what Robin Visser called the production of a post-socialist urban aesthetics. ${ }^{31}$ Specifically, it identifies three interrelated 'heritage vehicles' used by the Chinese authorities to create a 'space of sensation' for the performance and display of heritage: namely, museumification, monumentation and ritualization. I use 'museumification' to refer to the process in which local history is crafted in museum spaces by using stage props, mannequins, dioramas and other exhibiting techniques; 'monumentation' refers to the construction of gigantic buildings and public spaces to commemorate local cultural heroes and 
promote tourism; 'ritualization' refers to local authorities' repetitious staging of reinvented or artificially invented festivals to celebrate local cultural heritage, construct new city brands and boost the tourist industry. Each performance has its own vocabularies, tricks and agenda. Together, they contribute to the production of an ostentatious show directed by the local authorities and scripted by the local cultural elites, in which, the city residents participate as crew and as spectators. While this paper touches upon the processes of selective use and reinvention of local history and tradition that the local authorities draw on in constructing their version of 'desirable heritage', its analytical focus on official perspectives and tactical practices in heritagemaking leads instead to an emphasis on the efficacy of heritagization in shaping urban space.

Jiangmen, where the research on which this paper is based was conducted, is a prefecture-level municipality situated in the western part of Pearl River Delta in Guangdong Province. The area now under the jurisdiction of Jiangmen was traditionally called Wuyi (五邑), literally 'five counties' referring to Xinhui, Taishan, Kaiping, Enping and Heshan. In 2015, it had a population of about 4.5 million. Due to its geographical proximity to the major sea ports from which domestic Chinese went abroad in the $19^{\text {th }}$ century, large numbers of poor peasants ventured abroad to search for a better life when the Qing Empire was forced to open up and allowed its subjects to go overseas. ${ }^{32}$ According to recently published official survey data, the administrative area of Jiangmen has a population of over 3.8 million Overseas Chinese, residing in over 107 countries and regions (including Hong Kong and Macao), with the biggest majority settling in North America and Southeast Asia. ${ }^{33}$ 


\section{Museumification: the Jiangmen Wuyi Overseas Chinese Museum}

Since the 1990s, the Chinese state has put growing emphasis on urbanization as the key strategy of China's modernization and globalization. The pressure on cities to take a leading role in regional as well as national socio-economic development has led to increasingly intense competition for reputation and status among cities of all levels. ${ }^{34}$ To this end, Chinese cities have tried to preserve and promote a version of heritage that distinguishes their city from others as an effective method of city branding. For analytical purposes and at the risk of over-simplification, it is useful to divide urban heritage practices in China into two main categories: the 'nostalgic' and the 'exotic'. In some areas (notably Han-populated central China), heritagization means the preservation and reintegration of city ruins or restoration of symbols of the glorious past to enhance the regional image of a city or area in the present. ${ }^{35}$ In some others, it is more about how to repackage a marginalised place in peripheral China by performing ethnic authenticity to arouse fantasies of the exotic among the Han majority and the international audience. ${ }^{36}$

Jiangmen partakes in this ongoing 'branding war' by making use of an alternative recourse, the diasporic heritage. In 2004, China's Central Television (CCTV) for the first time organized a high-profile competition among China's second-tiered cities for the title of 'the ten most charming cities in China' (中国十大鬼力城市). Jiangmen entered this competition but failed to be listed. This incident shocked the local authorities and cultural elites, alerting them to the fact that Jiangmen had not yet accumulated enough well-recognized cultural resources to brand itself and compete with other municipalities. Lacking the kind of nostalgic and/or exotic appeal of other 
cities, the municipal government of Jiangmen determined to make use of its Overseas Chinese heritage as the city's distinctive feature, and started to tout the slogan of Jiangmen as 'China's number-one hometown of Overseas Chinese'（中国第一侨 乡) .37

The use of public slogans to promulgate official discourses has long characterized the political culture of contemporary China, not least in the form of omnipresent revolutionary slogans and posters of the Mao era. ${ }^{38}$ In a 2015 issue of this journal, Meiqin Wang discussed how the conceptual artist Ni Weihua coined the term 'language event' to denote the changes in the political rhetoric from Deng Xiaoping to Hu Jintao. ${ }^{39}$ While Ni brought to our attention the power (and irony) of political sloganeering employed by the Chinese government at the national level, the same can be said about city-branding at the local level as this case study shows. When the municipal government of Jiangmen put forward its bold and unprecedented claim to be 'China's number-one hometown of Overseas Chinese', it received immediate opposition from experts on the history of Overseas Chinese in other cities. Even some local residents and historians were doubtful about the validity of the claim. ${ }^{40}$ No other Chinese city had ever made such a statement before. Traditionally, Overseas Chinese originated from many different areas in the provinces of Guangdong and Fujian and elsewhere in China. It is technically impossible to give a ranking to them to say which one is number one. Indeed, in terms of the size of population residing overseas - a criterion commonly used to quantify the size of hometowns of Overseas Chinese Jiangmen is outnumbered by some other cities. ${ }^{41}$ 
The city's branding enterprise however received strong backing from local cultural elites. When asked about the controversial nature of the city's new slogan, a professor from Wuyi University, also a key figure behind the city's branding project, unequivocally defended the local government's position:

It is the duty of local government to make the fullest use of local historical and cultural resources to enhance a city's profile, so as to secure broader spaces for urban development ... there is nothing wrong in 'creating histories' for the sake of promoting city image, and to this end, it is absolutely right for the municipal government to promote the idea of Jiangmen as 'China's number-one hometown of Overseas Chinese' ${ }^{42}$

In order to to convince the general public that it was acceptable to use 'China's number-one hometown of Overseas Chinese' as the city's new 'business card', it became essential to build a museum where 'scientific' evidence of Jiangmen as a primary hometown of Overseas Chinese could be displayed. ${ }^{43}$ It was against this background that the local government laid the foundation stone to the Jiangmen Wuyi Overseas Chinese Museum in 2004. The aims in building the museum were summarized in three points by Mr. Li Wei, then deputy mayor of Jiangmen:

The first is to remember the bitter history of Overseas Chinese; the second is to recognize and cherish their great contributions to China and to use their stories to educate the younger generation; the third is to represent the Wuyi Overseas Chinese spirit ... to enhance our city's economic development, and to speed up the construction of Jiangmen as one of China's prominent cultural cities. ${ }^{44}$ 
It is the third point concerning local economic development and city branding, that is the biggest driving force behind the museum project. The municipal government offered strong administrative and financial support to the construction of the museum. Despite the fact that Jiangmen had the second lowest annual income among all prefectures in Guangdong, the municipal government spent approximately 100 million yuan RMB on object collection and museum construction, and invited the Guangzhou-based Zhujiang Film Studio to take charge of its interior design. When the museum was fully opened in 2010 , it was reportedly the most comprehensive and modern museum of Overseas Chinese in China. ${ }^{45}$

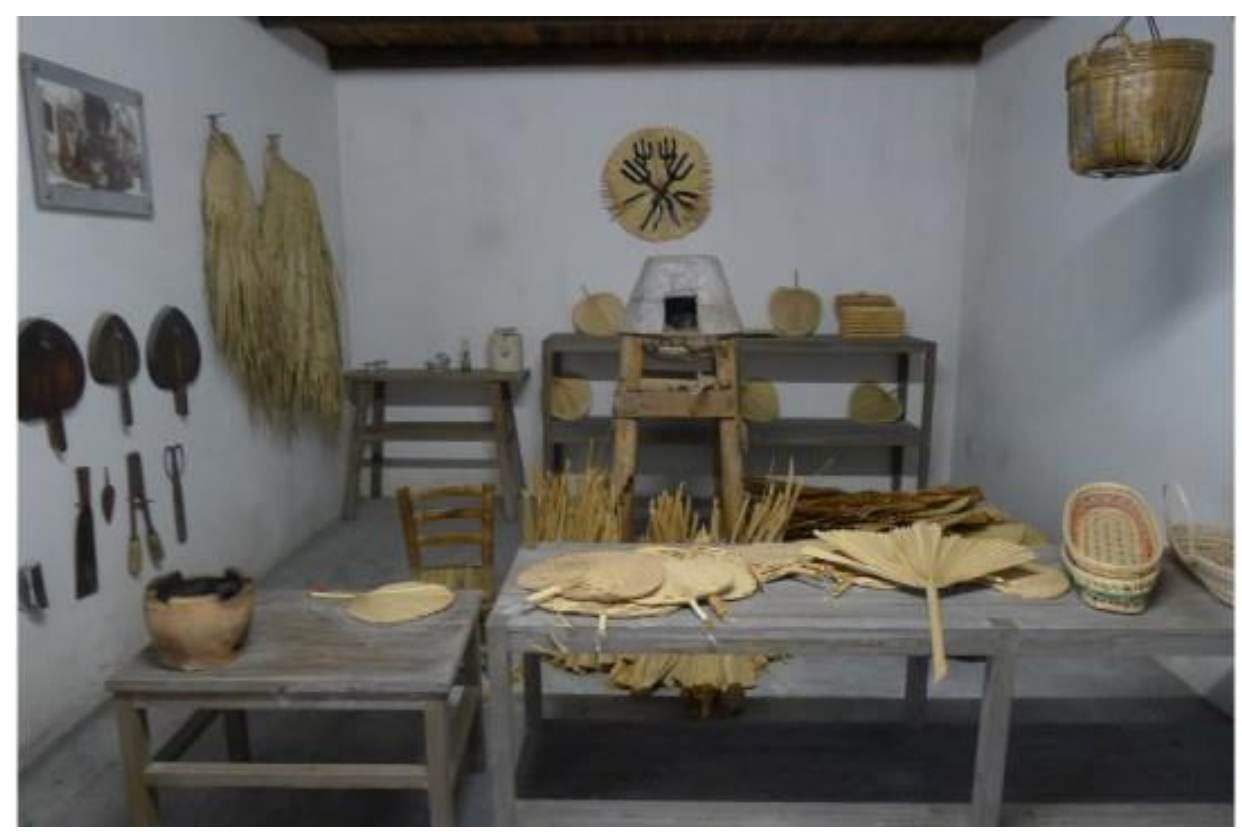

Figure 1: A shop in the local market place of 1860s Wuyi (photo by author)

The narrative of Overseas Chinese history exhibited in the museum is chronologically organized to display the history of Chinese emigration from the mid-nineteenth century to the present; it is not substantially different to that of other Overseas Chinese museums I have visited. What really struck me as distinctive was its theatrical representation of Overseas Chinese history unseen in other museums. 
Firstly, it explicitly draws on stage design techniques, such as play sets, props and costumes, to exhibit local migration history. The first scene the visitors came across on entering the museum is a local market place in 1860s Wuyi. Several life-sized shops have been constructed in the museum's main hall to visualize traditional village life (figure 1). However, none of the items on display - the furniture, working tools and everyday utensils - are authentic objects. Rather, they are all brand-new 'theatrical props' manufactured by the film studio and used by the museum to 'act out' the past. The next scene depicts a pier where villagers boarded ships to go overseas. Again, the stone steps leading to the pier, the gate of the pier, the plaque on the top of the gate and the ship moored by the pier, are all purpose-made props to perform the history of migration through dramatizing the moment of departure. It is apparent that what matters to the museum authority is not so much preserving and exhibiting historical authenticity, but rather the degree of 'theatrical effect' of its displays. Stage design techniques of these kinds are used throughout the remainder of the exhibition.

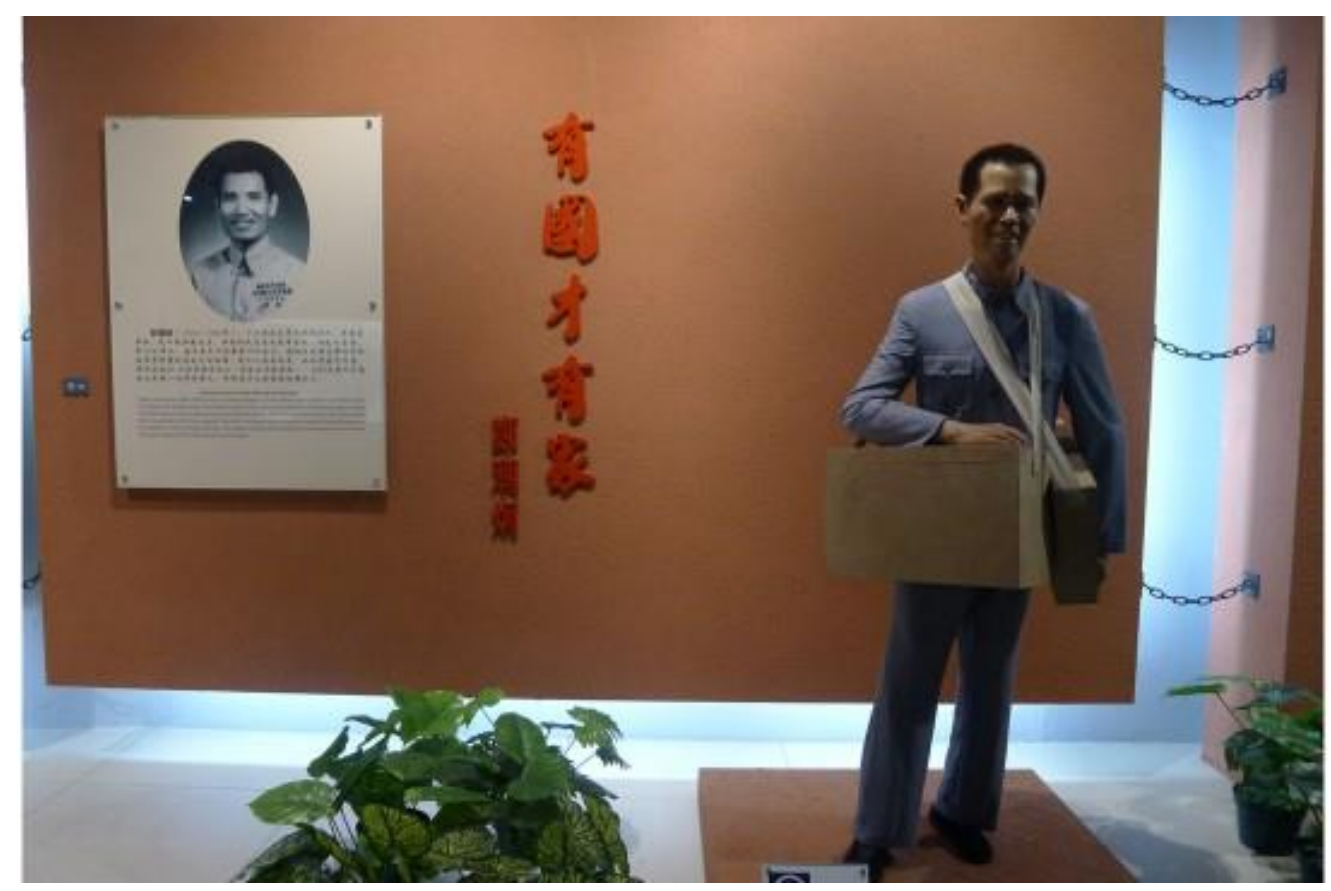

Figure 2: The model of Mr. Zheng displayed inside the museum (photo by author) 
The second main theatrical technique employed by the museum is the use of mannequins to highlight key figures and themes in the history of Overseas Chinese. One of the most dramatic is the story of an Overseas Chinese called Zheng Chaojiong who 'sold his son to save the nation' (figure 2). Mr. Zheng was a pedlar who made a living by selling sunflower seeds in Malaya. In order to support China's War of Resistance against Japan, he joined the fundraising campaign among Overseas Chinese by saving money from selling sunflower seeds. When his fourth son was born, he sold the new-born baby boy into adoption by a rich Chinese family and donated the money he received to China. To highlight Mr. Zheng's patriotic story - described as 'the treasure of museum' by the curator - there is a life-sized model of Mr. Zheng in a specially-designed space inside the museum. Behind the model stands a screen displaying his photograph, a short biography and his 'family instruction': 'Without a country families have nowhere to settle'.

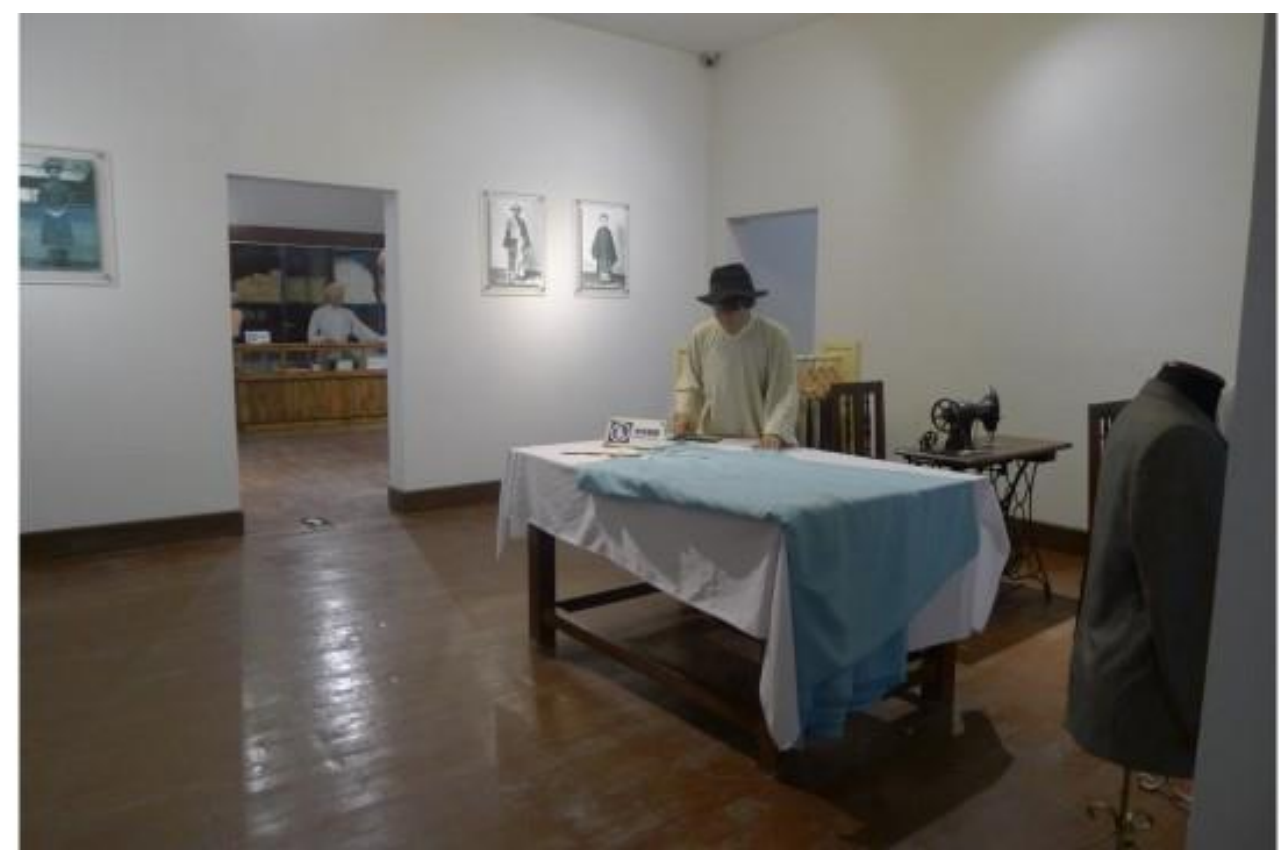

Figure 3: A tailor shop displayed in the scene of Chinatown (photo by author) 
In her study of China's ethnic minority museums, Marzia Varutti argued that the mannequin 'depersonalizes the object in order to enable the generalization of the representation'. ${ }^{46}$ Here, similarly, the museum intends to use Mr. Zheng's model to generalize the reality of the story it tells. By presenting this story of self-sacrifice as the very 'treasure' of the exhibition, the museum plays up to the patriotic discourse of Overseas Chinese promoted by the Chinese party-state. In so doing, it seeks to obtain recognition as the true representative of Overseas Chinese history, thus elevating Jiangmen's city image.

Thirdly, the museum makes extensive use of dioramas to simulate the working and living environments of Overseas Chinese. Examples include a Chinese restaurant, a tailor shop, a pharmacy, a laundry and a barber shop displayed in the scene of Chinatown (figure 3). By using dioramas in combination with mannequins, the museum seeks to bring to life the past experience of Overseas Chinese and the material world in which they lived. The use of diorama and mannequins received mixed responses from the audience. While some thought they helped visualize the history of Overseas Chinese, for others, the artificiality of the mannequins ironically produced the opposite effect to what the museum intended. One visitor commented that the dioramas and models looked like decorations, irrelevant to the real life of Overseas Chinese they had known. ${ }^{47}$ Others said they had expected to see more authentic objects related to Overseas Chinese history on display. ${ }^{48}$

Despite such criticisms, local official newspapers hailed the museum as Jiangmen's 'landmark building' and an ideal window to showcase its local history and unique culture. ${ }^{49}$ By using stage props, mannequins and dioramas as crafting devices, the 
museum attempted to produce what E. Cohen and S. A. Cohen called 'hot authentication', a process aimed at stimulating an affective and self-reinforcing response in which the projected 'real' is confirmed, in contrast to 'cool authentication' defined as certification of an object as original or genuine. ${ }^{50}$ The municipal government presented Jiangmen simultaneously as a heritage site, a base for patriotic education, a tourist spot and a prominent cultural city. Since 2010, the museum has received regular visits of civil servants, primary, secondary school and university students, and occasional visits of senior party and government officials from Beijing. The opening of this museum has been widely regarded as a major reason for the city's success in being listed as one of China's 'Civilized Cities of the Nation' (全国文明城市) in 2011, a big step forward in its branding enterprise. ${ }^{51}$

\section{Monumentation: Wuyi Overseas Chinese Square, Scholar Street and Star Park}

At the same time as they were developing the theatrical representation of Overseas Chinese history in the space of the museum, the local authorities dramatically transformed the city's landscape into an 'open-air theatre' to stage its diasporic heritage. Indeed, at a time when urban space has become a crucial element in China's economic success and new global status, 'the most forceful language that the government can speak is the language of controlling the urban space itself ${ }^{52}$ Here, the re-spacing of urban topographies is realized through the vehicle of what could be called monumentation: the construction of titanic architectures in purpose-built public spaces as the embodiment of heritage and its tourist appeal. 


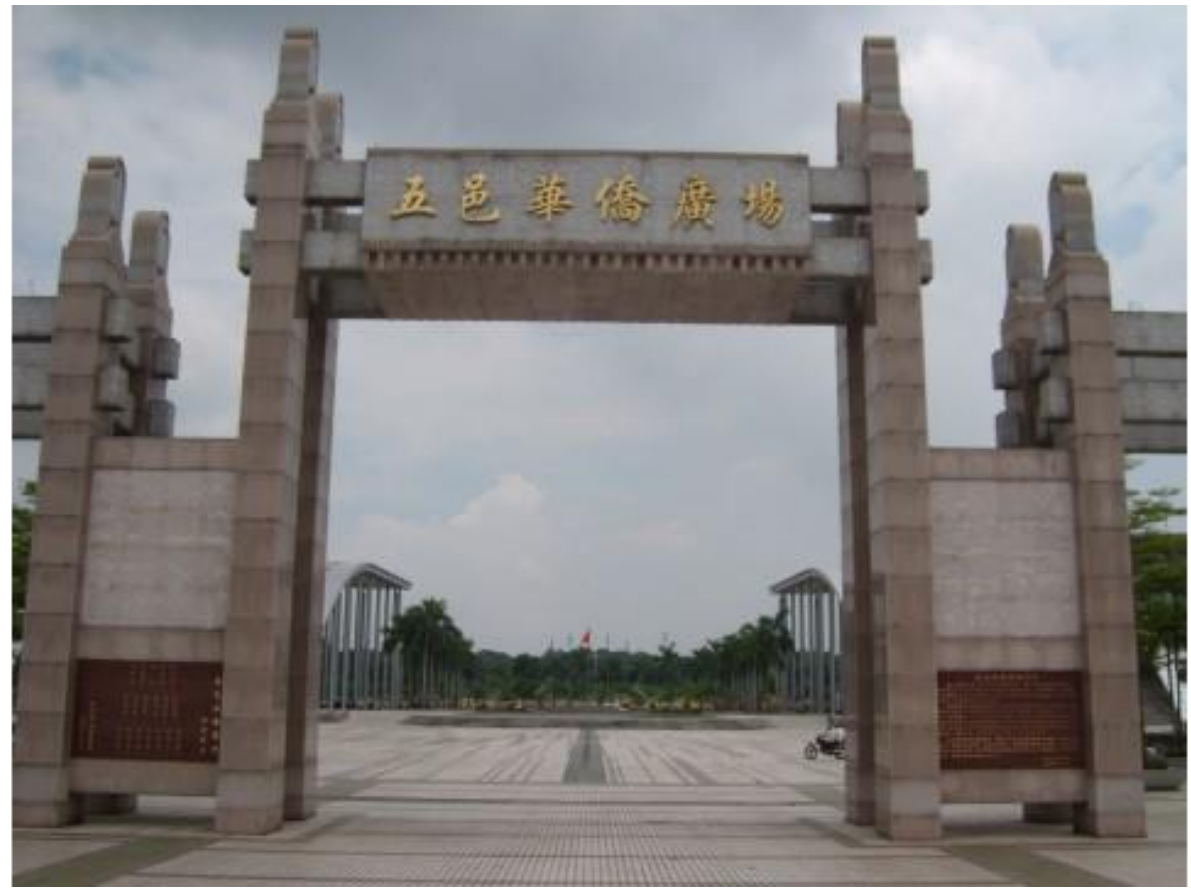

Figure 4: The main entrance to Wuyi Overseas Chinese Square (photo by author)

In Jiangmen, this monumentation is centred on the construction of a massive square in the centre of the city (figure 4). Just as the museum was named after Wuyi Overseas Chinese to stress the linkage between the city's past as a sending area of Overseas Chinese in history and its present as a modern city, the square was called Wuyi Overseas Chinese Square. The huge square, built in 2004, measures 61,766 square metres, and is surrounded by a modern exhibition hall, a state-of-the-art conference centre and an art gallery. It is also the location of the Overseas Chinese Museum. A gigantic stone gate in the style of a traditional memorial archway was erected as the main entrance to the square, the name of which was inscribed on the top of the gate in traditional 'full-form' Chinese characters, in symbolic reference to Hong Kong, Macao, Taiwan and Overseas Chinese communities where full-form characters are commonly used, in contrast to the simplified characters used elsewhere in China. The 
square thus announced its role as a symbolic 'rallying point' for Wuyi-originated peoples dispersed outside mainland China.

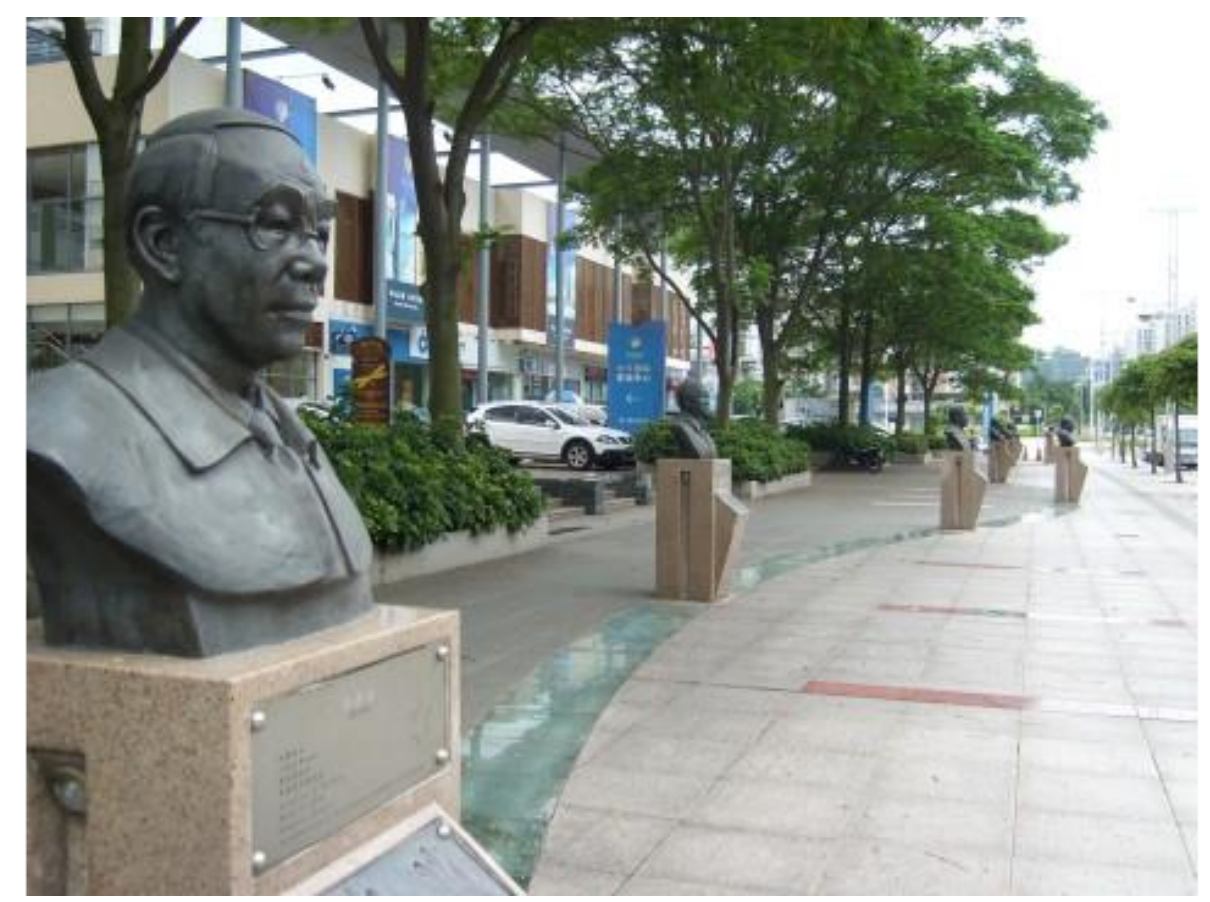

Figure 5: A view of Scholar Street (photo by author)

Shortly after building Wuyi Overseas Chinese Square, the municipal government launched another branding project - Scholar Street - starting right from the main entrance of the square (figure 5). Along both sides of this one hundred-metre-long street stand a total of 31 bronze busts of prominent Chinese scholars. Over half of them are foreign nationals or Taiwan and Hong Kong residents. They are however considered to belong to Wuyi either by birth or by place of origin. Each pillar supporting the busts stand is decorated with two bronze plaques. The upper one records the name, place of origin and specialty of the scholar, in both Chinese and English; the lower one is engraved with the scholar's handprints. 


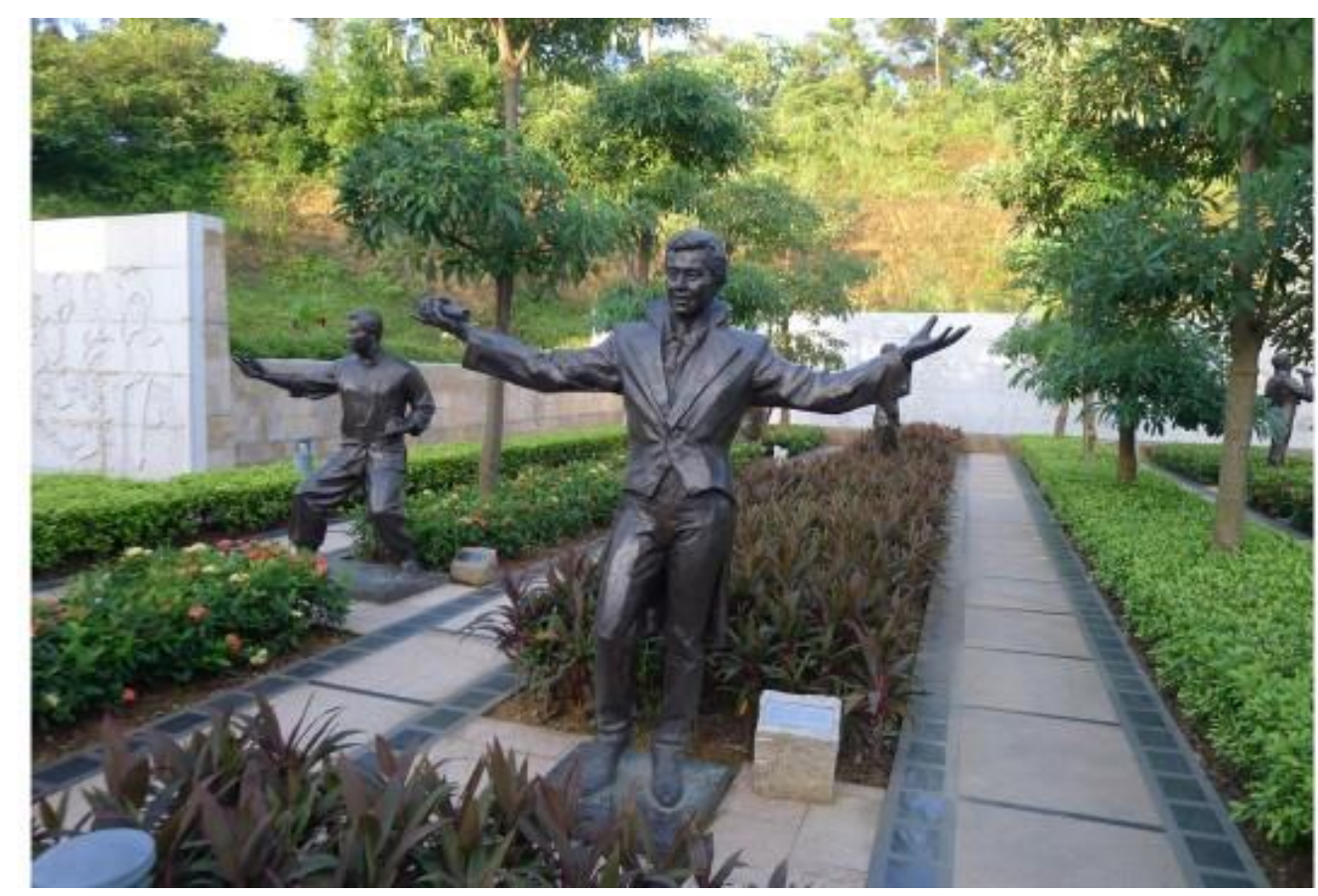

Figure 6: A corner of Star Park (photo by author)

In a similar style, from 2009 to 2010, the municipal government built another public space called Star Park (figure 6), covering an area of 14,000 square metres. In the central area of the park stand 124 life-sized bronze statues of Chinese pop singers and film stars, the majority of them being Hong Kong residents with Wuyi as the place of origin. ${ }^{53}$ At the side of each statue is a plaque recording the name, place of origin and a short biography of the artist. In a separate space inside the park are a number of stone stands bearing handprints and signatures of the most popular artists. The building of this theme park, as stated in the inscription on its Chronicle Tower of Star Park, is 'to improve the cultural status of our city and to speed up the construction of a distinguished cultural city in Jiangmen'. The inscription goes on to say, 'the park is comparable to the Walk of Fame in Hollywood and the Avenue of Stars in Hong Kong ... a wonderful modern artwork added to Jiangmen's cultural landscape'. 
The bronze statues in Scholar Street and Star Park are strikingly similar, despite their differences. The variations between them in terms of occupation, age, sex and physical features are almost totally flattened out in their design and display. Whether scholars or artists, young or old, men or women, they are all presented as anonymous 'pop stars' or celebrities to wow the local residents and attract domestic and international tourists. They are all what Charles Peirce called 'symbolic signs ${ }^{, 54}$ deployed by the local authorities to visualize the city's cultural distinction, magnify its international influence, and ultimately justify the claim that Jiangmen is 'China's number-one hometown of Overseas Chinese'.

Natalie Koch discussed how the 'monumental presentation' of Astana contributed to the elite definition of a modern and forward-looking Kazakhstan identity. ${ }^{55}$ Similarly, through the monumentation exercise discussed above, the local authorities and cultural elites of Jiangmen have sought to create a new 'mental map' defined by the city's diasporic heritage. Their aim in so doing has been to give the city a new brand and embed its new identity in collective memory as a desirable place on a transnational platform.

\section{Ritualization: staging the Overseas Chinese Carnival}

In the same year as it laid the foundation stone to the Wuyi Overseas Chinese Museum, constructed Wuyi Overseas Chinese Square and launched Scholar Street, Jiangmen's municipal government kicked off an unprecedented event - a biannual Overseas Chinese Carnival. By the time of writing this paper, the city had hosted a 
total of five carnivals, the last of which was in 2013. Each carnival was held between the mid-October and early November, lasting for an average of three days.

'Carnival' is a notion and custom that originated from medieval Europe and gradually spread to other parts of the world. Following Bahktin, carnival is a cultural practice characterized by the expression of free spirits challenging the authorities and (symbolically) overturning the social hierarchies of everyday life, often associated with humour, mockery and anarchic celebrations. ${ }^{56}$ Despite carrying a Western label, the nature of the Overseas Chinese Carnival is fundamentally different from, if not contradictory to, how carnival is defined and practised in the Western tradition. The purpose for launching the Overseas Chinese Carnival, as explained by the Party Secretary of Jiangmen in his speech at the opening ceremony of the debut Carnival, was '... to exhibit Jiangmen's great achievements in economic reform, ... spread its influence in China and strengthen its exchange and cooperation with the world' ${ }^{57}$

Clearly, the Overseas Chinese Carnival is a campaign orchestrated by the local authorities to achieve specifically-defined political and economic goals. The periodically staged Carnival is better seen as an 'invented tradition' that 'seek(s) to inculcate certain values and norms of behaviour by repetition, which automatically implies continuity with the past ... or which establish their own past by quasiobligatory repetition'. ${ }^{58}$ Here, the 'past' that local authorities intend to invoke is the diasporic legacy associated with the place of Wuyi, and the 'value' they intend to inculcate is the perception of Jiangmen as a cultural city with international status. Indeed, by artificially transplanting a foreign custom to Chinese soil, the local authorities and cultural elites have created a much-needed cultural vehicle to summon, 
perform and sustain the city's diasporic heritage, to give the city a global feel, and ultimately to promote Jiangmen as a renowned cultural city.

What inventing traditions is essentially about, as argued by Eric Hobsbawm and Terence Ranger, is 'a process of formalization and ritualization' often characterized by imposing repetition. ${ }^{59}$ Despite variations in the specific theme for each Carnival, they have all largely followed the same format and set of procedures. The municipal government is the organizer and main sponsor of each Carnival. Each time, the Carnival kicks off with an ostentatious opening ceremony. The Party Secretary of Jiangmen gives important speeches in front of the general audience and several hundred domestic and overseas VIP guests. The highlight is a splendid parade that takes place at the end of the opening ceremony. The parade normally lasts for two hours, involving the participation of some two thousand performers from local areas and overseas. Each time, it attracts approximately 200,000 to 500,000 local residents who watch along the main streets where the parade passes by. In the following days, a wide range of activities are routinely carried out, including government-sponsored forums, variety shows, food festivals, and so on.

The official media has commended the Carnival as a great innovation that has successfully developed a taste for high culture in the city. ${ }^{60}$ In this sense, and from the perspective of its architects, the periodically staged Carnival could be thought of as a ritual to enchant the city and people, used by the local authorities to give the city a new face and new life. While the museum and the monuments are silent and static objects, the ostentatious Carnivals have brought to the theatre of the city's heritage the noises, smoke, colours, scents and excitement it so obviously needed, with the 
intention of keeping the audience persistently captivated. The enchantment is not opposed to modernity and development. On the contrary, it is used by the local authorities and cultural elites to construct a modern present and a cosmopolitan future.

The Carnival received more critique than applause from the residents of Jiangmen. Some complained that they had no real connections with the Carnival and little involvement in the event. Those who did have opportunities to participate did not see how such a costly event did anything particularly useful to boost the city's reputation. ${ }^{61}$ However, there is no sign that the authorities of Jiangmen will give up the musicological, spatial and ritual practices it has employed in recent years to promote its city image. In 2015, the municipal government announced its new Fiveyear Plan with the chief target being to develop Jiangmen from 'China's number-one hometown of Overseas Chinese' to 'China’s capital of Overseas Chinese' (中国侨都) by $2020 .^{62}$ The show certainly goes on.

\section{Conclusion}

This paper applies the concept of 'theatre', inspired by Geertz's notion of 'theatre state', to the study China's heritage industry in urban space. Drawing on a case study of Jiangmen, it discusses three interrelated vehicles, namely, 'museumification', 'monumentation' and 'ritualization', which the local authorities have skilfully employed to make cultural heritage in urban space. The museum is where the local history of Overseas Chinese is 'scientifically' framed and theatrically presented to offer evidence in support of the slogan that Jiangmen is 'China's number-one hometown of Overseas Chinese'; Wuyi Overseas Chinese Square, Scholar Street and 
Star Park are monuments constructed to produce a sensational spectacle with the same message. They have not only materialized the history and glory of the place, but also transformed the city's landscape into a perfect setting for staging the biannual Overseas Chinese Carnival. The Carnival is a ritual in the sense that it seeks to enchant the place and people by inventing its own tradition rooted in periodic staging. The intersections of these vehicles have contributed to the formation of a 'theatre' of heritage, in which the local authorities are the producer, the local cultural elites the director and playwright, and the city residents and visitors, crew and spectators. Instead of preserving and utilizing cultural authenticity for the creation of an orderly model city - although this is certainly one aspect of state-led heritage work - the local authorities and cultural elites have made tremendous efforts to put on a series of spectacular and sometimes chaotic shows to conjure up a desirable heritage underpinning its city brand and identification as a desirable place.

Rather than emphasizing the speciality of Jiangmen as a hometown of Overseas Chinese, this paper is an attempt to identify an emergent feature of China's fastdeveloping heritage industry, reflective of 'an increased degree of commonality in lived experience and communicative practice ${ }^{63}$ characterising the socio-cultural development in post-socialist China. Following Saler who defined modernity as 'a disenchanted enchantment' ${ }^{64}$ this paper challenges the mainstream view that conceptualizes heritage as a civilizing agent to modernize the urban population. Instead, it suggests strongly that China's state-led heritage-making, whether it draws on nostalgic, exotic or diasporic resources, is as much 'a technique of enchantment' as a 'technique of government', and reveals complicated processes involved in China's negotiation with the universalistic European-inspired conceptualization of modernity 
and cultural heritage. This new conceptual understanding of cultural heritage remedies the highly rationalized theorization of Chinese heritage in the existing literature, and has larger implications for the study of heritage and urbanization in non-Western countries, the fuller understanding of which requires more contextualized investigation beyond the Western-centred perspective of modernity.

\section{Notes}

Field trips to China related to this research were founded by Co-ordination of Research between Europe and China on Cultural Heritage in China (Co-Reach) and Universities's China Committee in London (UCCL). I would like to thank Harriet Evans for her supportive advice and the two anonymous reviewers for their helpful comments and suggestions.

1. Harriet Evans and Mike Rowlands, Reconceptualizing heritage in China: Museums, development and the shifting dynamics of power, in Paul Basu and Wayne Modest (eds) Museums, Heritage and International Development, London: Routledge, 2015, 272-94.

2. Tim Oakes, Tourism and Modernity in China, London: Routledge, 1998; Tami Blumenfield and Helaine Silverman (eds) Cultural Heritage Politics in China, New York: Springer, 2013; Pal Nyiri, Scenic Spots: Chinese Tourism, the State, and Cultural Authority, Seattle, WA: University of Washington Press, 2006.

3. Xiaobo Su and Peggy Teo, The Politics of Heritage Tourism in China: A View from Lijiang, London: Routledge, 2009; Timothy S. Oakes, The cultural space of modernity: Ethnic tourism and place identity in China, Environment and Planning D: Society and Space 11(1), 1993: 47-66; T. Chang, S. Milne, D. Fallon and C. Pohlmann, Urban heritage tourism: The global-local nexus, Annals of Tourism Research 23(2), 1996: 284-305.

4. Oakes, Tourism and Modernity in China; Chin-yu Shih, Negotiating Ethnicity in 
China: Citizenship as A Response to the State, London: Routledge, 2002; Li Yang, Ethnic tourism and cultural representation, Annuals of Tourism Research 38(2), 2011: 561-85.

5. Yingchun Zhang and Zongjie $\mathrm{Wu}$, The reproduction of heritage in a Chinese village: Whose heritage, whose pasts?, International Journal of Heritage Studies 22 (3), 2016: 228-41; Haiming Yan, World Heritage as discourse: Knowledge, discipline and dissonance in Fujian Tulou sites, International Journal of Heritage Studies 21(1), 2015: 65-80; Marina Svensson, In the Ancestors'Shadow: Cultural Heritage Contestations in Chinese Villages (working paper No. 17., Centre for East and South-East Asian Studies, Lund University, 2006); Tim Oakes, Villagizing the city: Turning rural ethnic heritage into urban modernity in southwest China, International Journal of Heritage Studies 22(10), 2016: 751-65.

6. Xuefei Ren, The political economy of urban ruins: Redeveloping Shanghai, International Journal of Urban and Regional Research 38 (3), 2014: 1081-91; To Lui, City-branding without content: Hong Kong's aborted West Kowloon megaproject, 1998-2006, International Development Planning Review 30(3), 2008: 215-26; Hilary Du Cros and Yok-shiu F. Lee, Cultural Heritage Management in China: Preserving the Cities of the Pearl River Delta, London: Routledge, 2011; Li Zhang and Xiaobin Zhao, City branding and the Olympic effect: A case study of Beijing, Cities 26(5), 2009: 245-54.

7. Li Fan, International influence and local response: understanding community involvement in urban heritage conservation in China, International Journal of Heritage Studies 20(6), 2014: 651-62; Zhengdong Luo, Xu Wang, Jingxiang Zhang and $\mathrm{Yi} \mathrm{Hu}$, Urban scaling-up and endogenous development promoted by continuous city marketing: A case study of Xuyi County, China, Planning Theory 
12(4), 2013: 406-24; Jinze Cui, Bargain with the soul of 'fake heritage': A study of the reconstruction of the historic centre of Datong and the related public debate in China (paper presented at Cultural Heritage in China: Contested Understandings, Images and Practices conference, Lund University, Sweden, June 2015).

8. Yawei Zhao, China's leading historical and cultural city: Branding Dali city through public-private partnerships in Bai architecture revitalization, Cities 49, 2015: 106-112; Oakes, Villagizing the city, 751-65.

9. Oakes, Villagizing the city, 754.

10. Tim Oakes, Heritage as improvement: Cultural display and contested governance in rural China, Modern China 39(4), 2012: 381.

11. Michael Foucault, Governmentality, in Graham Burchell, Colin Gordon and Peter Miller (eds) The Foucault Effect: Studies in Governmentality, Chicago: the University of Chicago Press, 1991: 87-104.

12. Oakes, Villagizing the city, 754.

13. Yi-Fu Tuan and Steven Hoelscher, Disneyland: Its place in world culture, in Karal Ann Marling (ed.) Designing Disney's Theme Parks: The Architecture of Reassurance, Paris: Flammarion, 1997: 192-98, cited in Oakes, Heritage as improvement, 400-01.

14. Ibid.

15. Evans and Rowlands, Reconceptualizing heritage in China, 277; Denise Y. Ho and Jie Li, From landlord manor to red memorabilia: Reincarnations of a Chinese museum town, Modern China 42(1), 2016: 3-37.

16. Yujie Zhu, When the global meets the local in tourism-Cultural performances in Lijiang as case studies, Journal of China Tourism Research 8(3), 2012: 302-19. 
17. Helen Siu, Recycling rituals: politics and popular culture in contemporary rural China, in Link Perry, Richard Madsen and Paul G. Pickowicz (eds) Unofficial China: Popular Culture and Thought in the People's Republic of China, Boulder: Westview Press, 1989, 121-37; Louisa Schein, The dynamics of cultural revival among the Miao in Guizhou, in Chien Chiao and Nicholars Tapp (eds) Ethnicity and Ethnic Groups in China, Chinese University of Hong Kong, 1989, 99-212; Emily Chao, Hegemony, agency and the re-presentation of the past: Dongba culture among the Naxi minority of southwest China, in Melissa Brown (ed.) Negotiating Ethnicities in China and Taiwan, Berkeley: University of California Press, 1996, 208-39.

18. Zhu, When the global meets the local in tourism, 311-13.

19. Ibid., 313.

20. See, for example, Dipesh Chakrabarty, Provincializing Europe: Postcolonial Thought and Historical Difference, Princeton, N.J. : Princeton University Press, 2007; Henrietta L. Moore and Todd Sanders (eds) Magical Interpretations, Material Realities: Modernity, Witchcraft, and the Occult in Postcolonial Africa, London: Routledge, 2001; Gyan Prakash, Another Reason: Science and the Imagination of Modern India, Princeton, N.J. : Princeton University Press, 1999.

21. Max Weber, Science as a vocation, in From Max Weber: Essays in Sociology, trans., edited and with an introduction Hans Heinrich Gerth and C. Wright Mills, New York: Oxford University Press, 1946, 129-56.

22. Michael Saler, Modernity and enchantment: A historiographic review, The American Historical Review 111(3), 2006: 692.

23. Saler, Modernity and enchantment, 700.

24. Simon During, Modern Enchantments: The Cultural Power of Secular Magic, 
Cambridge, Mass.: Harvard University Press, 2002, 66-71.

25. Saler, Modernity and enchantment, 702-14.

26. Zhu, When the global meets the local in tourism, 316.

27. Clifford Geertz, Negara: The Theatre State in Nineteenth Century Bali, Princeton, N.J.: Princeton University Press, 1980.

28. Ibid., 13.

29. See, for instance, Heonik Kwon and Byung-Ho Chung, North Korea: Beyond Charismatic Politics, Lanham, MD: Rowman \& Littlefield, 2012; Garry Wills, Making Make-Believe Real: Politics as Theatre in Shakespeare's Time, New Haven: Yale University Press, 2014; Joseph W. Esherick and Jeffrey N. Wasserstrom, Acting out democracy: Political theatre in modern China, The Journal of Asian Studies 49(4), 1990: 835-865; Elizabeth Helen Essary and Christian Ferney, Pomp and power, performers and politicians: The California theatre state, American Journal of Cultural Sociology 1(1), 2013: 96-124.

30. The emergent literature on Chinese urbanities and arts examines how China's urbanism shapes and is shaped by popular culture, see Jeroen de Kloet and Lena Scheen (eds) Spectacle and the City: Chinese Urbanities in Art and Popular Culture, Amsterdam: Amsterdam University Press, 2013. This bunch of studies however does not discuss the production and representation of cultural heritage in particular.

31. Robin Visser, Cities Surround the Countryside: Urban Aesthetics in Postsocialist China, Durham, NC: Duke University Press, 2010, 4.

32. Mei Weiqiang 梅伟强 and Zhang Guoxiong 张国雄 (eds), 五邑华侨华人史 (The History of Wuyi Overseas Chinese), Guangzhou: 广东高等教育出版社 (Guangdong Gaodeng Jiaoyu Chubanshe), 2001. 
33. Mei Weiqiang 梅伟强, 从侨情调查看江门五邑侨乡特色 (Identifying the characteristics of Jiangmen Wuyi from the study of a recently published survey of Overseas $\quad 2$ Chinese), 2002, http://www.southcn.com/news/gdnews/hotspot/sylhsy/sylh/lhqiaoqing/200212020 868.htm, accessed 18 April 2016.

34. Fulong Wu, Beyond gradualism: China's urban revolution and emerging cities, in Fulong Wu (ed.) China's Emerging Cities: The Making of New Urbanism, London and New York: Routledge, 2007, 3-25; Thomas J. Campanella, The Concrete Dragon: China's Urban Revolution and What It Means for the World, Princeton, NJ: Princeton University Press, 2008.

35. Cui, Barging with the soul of 'fake heritage; Ren, The political economy of urban ruins, 1081-91; Zhang and Zhao, City branding and the Olympic effect, 245-54.

36. Zhao, China's leading historical and cultural city, 106-12; Oakes, Villagizing the city, 751-65; Zhu, When the global meets the local in Tourism, 302-19.

37. Li Guisheng et. al. 李桂生等, 首届 “最佳魅力城市” 评选落榜：沉默不是金 (Jiangmen lost in the first 'China's most charming city' competition: silence is not gold), 21 March 2005, 江 门 日 报 (Jiangmen Daily) http://www.southen.com/news/dishi/jiangmen/shizheng/200503210637.htm, accessed 16 June 2015.

38. Harriet Evans and Stephanie Donald (eds) Picturing Power in the People's Republic of China: Posters of the Cultural Revolution, Lanham, Md.: Rowman \& Littlefield, 1999.

39. Meiqin Wang, Advertising the Chinese dream: Urban billboards and Ni Weihua's documentary photography, China Information 29(2), 2015: 176-201.

40. Author's interview with Professor A, Jiangmen, 14 August 2010. 
41. Huang Jing 黄静, 潮汕与中国传统侨乡: 一个关于移民经验的类型学分析 (Chao-Shan and China's traditional hometowns of Overseas Chinese: A typology), 华侨华人历史研究 (Overseas Chinese History Studies), no. 1, 2003: 24-36.

42. Author's interview with Professor A, Jiangmen, 14 August 2010. All quotations presented in this paper are author's translation.

43. Jiangmen is not exceptional in the use of museums for promoting city image. For example, Chifeng Museum used the cultural and political achievement of Kitan in history to bolster the city's claim to uniqueness. See Naomi Standen and Gwen Bennett, Difficult histories: Changing presentations of the Liao in regional museums in the People's Republic of China over three decades. Modern Asian Studies 48 (6), 2014: 1542.

44. Yang Huimin 杨慧敏, 五邑华博馆: 侨乡地标 城市之魂 (Wuyi Overseas Chinese Museum: the landmark of a hometown of Overseas Chinese, and the spirit of the city), 江门日报 (Jiangmen Daily), 7 December 2009, Issue 7373: A03, http://dzb.jmrb.com:8080/jmrb/html/2009-12/07/content_143281.htm, accessed 10 June 2016.

45. The museum was opened in 2005 for a trial. It went through continuous renovation and was officially opened in 2010 . The museum currently hosts over 40,000 items, and is widely regarded as the largest collection of its kind in China. Author's interview with the museum director, Jiangmen, 2 August 2013.

46. Marzia Varutti, Miniatures of the nation: ethnic minority figurines, mannequins and diorama in Chinese museums, Museum and Society 9(1), 2011: 1-16.

47. Yaogongchong zld 摇滚虫 zld, 江门五邑华侨博物馆带出的问题 (Comments on the problems of Jiangmen Wuyi Overseas Chinese Museum), 7 January 2011, 
http://wz.wen.oeeee.com/Content/67350.htm, accessed 7 June 2016.

48. Notes from the museum's Comment Book, Jiangmen, 3 August 2013.

49. 五邑华侨博物馆：游走史间 思接当年 (Wuyi Overseas Chinese Museum: In dialogue with the past, thinking about the Future), 江门日报 (Jiangmen Daily), 23 November 2005, http://www.chinaqw.com/news/2005/1123/68/6509.shtml, accessed 10 June 2016.

50. E. Cohen and SA. Cohen. Authentication: Hot and cool, Annals of Tourism Research 39(3), 2012: 1295-1314.

51. 'Civilized Cities of the Nation' is an honorary title that Central Spiritual Civilization Construction Leadership Committee of the Chinese Communist Party awards to Chinese cities as recognition of their overall achievements in Socialist construction. The award takes place every three years, starting from 2005. As it is regarded as the highest honour available to a city, competitions for getting and keeping this title is high; author's interview, Jiangmen, 2 August 2013.

52. Jacob Dreyer, Shanghai and the 2010 Expo: staging the city, in Gregory Bracken (ed.) Aspects of Urbanization in China: Shanghai, Hong Kong, Guangzhou, Amsterdam: Amsterdam University Press, 2012, 50.

53. Names of the scholars and artists were provided by Jiangmen Municipal Archive Bureau. At the request of the municipal government, the bureau compiled a comprehensive list of renowned Overseas Chinese with recorded evidence of Wuyi origin.

54. Charles Peirce, Logic as semiotic: the theory of signs, in Philosophical Writings of Peirce, selected and edited with an introduction by Justus Buchler, New York: Dover Publications, 1995: 95-119.

55. Natalie Koch, The monumental and the miniature: Imagining 'modernity' in 
Astana, Social \& Cultural Geography 11(8), 2010: 770.

56. Mikhail Bakhtin, Rabelais and His World, Trans. Helene Iswolsky, Bloomington: Indiana University Press, 1984.

57. Xing Liyu 邢利宇, 中国江门举办侨乡华人嘉年华 两千华人欢聚一堂 (Jiangmen hosting Overseas Chinese Carnival, two thousand guests happily gathering together), 中国新闻网 (China News Net), 18 October 2004, http://www.chinanews.com/news/2004/2004-10-18/26/495446.shtml, accessed 7 June 2016.

58. Eric Hobsbawm and Terence Ranger (eds) The Invention of Tradition. Cambridge: Cambridge University Press, 1983, 1-2.

59. Ibid., 4.

60. Bi Shiming 毕式明 and Lin Sheng 林盛, 打造品牌 嘉年华拓展侨乡文化内涵 (Branding: Overseas Chinese Carnival enriches Jiangmen's urban culture), 南方 日报 (Nanfang Daily), 18 October 2004, http://www.southcn.com/news/dishi/jiangmen/ttxw/200410180066.htm, accessed 29 June 2016.

61. Zhang Maosheng 张茂盛, Ou Jingchang 区景常 and Chen Sumin 陈素敏，明年 嘉年华如何办? 市委宣传部向各方问计 (How to run next year's Overseas Chinese Carnival? The Propaganda Department consulted specialists), 江门日报 $\begin{array}{lllll}\text { (Jiangmen } & \text { Daily), } & 28 & \text { November }\end{array}$ http://www.jiangmen.gov.cn/zwgk/ztbd/2013jnh/201211/t20121128_353634.html, accessed 29 November 2016.

62. Tian Wei 田伟，江门首发侨务“十三五”蓝图 吹响侨都建设号角(Jiangmen released the 13th Five-year Plan for Overseas Chinese affairs, blowing the trumpet 
for building Jiangmen into China's capital of Overseas Chinese), 人民网 (People's Net), 13 October 2015, http://www.chinaqw.com/gqqj/2015/1013/66812.shtml, access 22 April 2016.

63. Andrew B. Kipnis, Constructing ccommonality: Standardization and modernization in Chinese nation-building, The Journal of Asian Studies 71(3), 2012: 731 .

64. Saler, Modernity and enchantment, 707.

\section{References}

Bakhtin, Mikhail (1984) Rabelais and His World. Trans. Helene Iswolsky. Bloomington: Indiana University Press.

Bi, Shiming 毕式明 and Lin, Sheng 林盛 (2004) 打造品牌 嘉年华拓展侨乡文化 内涵 (Branding: Overseas Chinese Carnival enriches Jiangmen's urban culture),

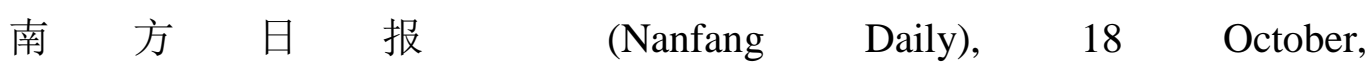
http://www.southcn.com/news/dishi/jiangmen/ttxw/200410180066.htm, accessed 29 June 2015.

Blumenfield, Tami and Silverman, Helaine (eds) (2013) Cultural Heritage Politics in China. New York: Springer.

Campanella, Thomas J. (2008) The Concrete Dragon: China's Urban Revolution and What It Means for the World. Princeton, NJ: Princeton University Press.

Chakrabarty, Dipesh (2007) Provincializing Europe: Postcolonial Thought and Historical Difference. Princeton, N.J.: Princeton University Press.

Chang, T., Milne, S., Fallon, D. and Pohlmann, C. (1996) Urban heritage tourism: The global-local nexus. Annals of Tourism Research 23(2): 284-305.

Chao, Emily (1996) Hegemony, agency and the re-presentation of the past: Dongba culture among the Naxi minority of southwest China. In: Brown, Melissa (ed.) Negotiating Ethnicities in China and Taiwan. Berkeley: University of California Press, 208-39.

Cohen, E., and Cohen, S. A. (2012) Authentication: Hot and cool. Annals of Tourism Research 39 (3): 1295-1314. 
Cui, Jinze (2015) Bargain with the soul of 'fake heritage': A study of the reconstruction of the historic centre of Datong and the related public debate in China. Paper presented at Cultural Heritage in China: Contested Understandings, Images and Practices conference, Lund University, Sweden, June.

Dreyer, Jacob (2012) Shanghai and the 2010 Expo: Staging the city. In: Bracken, Gregory (ed.) Aspects of Urbanization in China: Shanghai, Hong Kong, Guangzhou. Amsterdam: Amsterdam University Press, 47-58.

Du Cros, Hilary and Lee, Yok-shiu F. (2011) Cultural Heritage Management in China: Preserving the Cities of the Pearl River Delta. London: Routledge.

During, Simon (2002) Modern Enchantments: The Cultural Power of Secular Magic. Cambridge, Mass.: Harvard University Press.

Esherick, Joseph W. and Wasserstrom, Jeffrey N. (1990) Acting out democracy: Political theatre in modern China. The Journal of Asian Studies 49(4): 835-65.

Essary, Elizabeth Helen and Ferney, Christian (2013) Pomp and power, performers and politicians: The California theatre state. American Journal of Cultural Sociology 1(1): 96-124.

Evans, Harriet and Donald, Stephanie (eds) (1999) Picturing Power in the People's Republic of China: Posters of the Cultural Revolution. Lanham, Md.: Rowman \& Littlefield.

Evans, Harriet and Rowlands, Michael (2015) Reconceptualizing heritage in China: Museums, development and the shifting dynamics of power. In: Basu, Paul and Modest, Wayne (eds) Museums, Heritage and International Development. London: Routledge, 272-94.

Fan, Li (2014) International influence and local response: Understanding community involvement in urban heritage conservation in China. International Journal of Heritage Studies 20 (6): 651-62.

Foucault, Michael (1991) Governmentality. In: Burchell, Graham, Gordon, Colin and Miller, Peter (eds) The Foucault Effect: Studies in Governmentality. Chicago: the University of Chicago Press, 87-104.

Geertz, Clifford (1980) Negara: the Theatre state in Nineteenth Century Bali. Princeton, N.J.: Princeton University Press.

Ho, Denise Y. and Li, Jie (2016) From landlord manor to red memorabilia: Reincarnations of a Chinese museum town. Modern China 42 (1): 3-37. 
Hobsbawm, Eric and Ranger, Terence (eds) (1983) The Invention of Tradition. Cambridge: Cambridge University Press.

Huang, Jing 黄静 (2003) 潮汕与中国传统侨乡: 一个关于移民经验的类型学分析 (Chao-Shan and China's traditional hometowns of Overseas Chinese: A typology). 华侨华人历史研究 (Overseas Chinese History Studies), no. 1: 24-36.

Kipnis, Andrew B. (2012) Constructing commonality: Standardization and modernization in Chinese nation-building. The Journal of Asian Studies 71(3): $731-55$.

Kloet, Jeroen de and Scheen, Lena (eds) (2013) Spectacle and the City: Chinese Urbanities in Art and Popular Culture. Amsterdam: Amsterdam University Press.

Koch, Natalie (2010) The monumental and the miniature: Imagining 'modernity' in Astana. Social \& Cultural Geography 11 (8): 769-87.

Kwon, Heonik and Chung, Byung-Ho (2012) North Korea: Beyond Charismatic Politics. Lanham. MD: Rowman \& Littlefield.

Li, Guisheng et. al. 李桂生等 (2005) 首届 “最佳鬼力城市” 评选落榜：沉默不是金 (Jiangmen lost in the first 'China's most charming city' competition: silence is not gold), 21 March, 江 门日 报 (Jiangmeng Daily), http://www.southcn.com/news/dishi/jiangmen/shizheng/200503210637.htm, accessed 16 June 2015 .

Lui, To (2008) City-branding without content: Hong Kong's aborted West Kowloon mega-project, 1998-2006. International Development Planning Review 30(3): $215-26$.

Luo, Zhengdong, Wang, Xu, Zhang, Jingxing and Hu, Yi (2013) Urban scaling-up and endogenous development promoted by continuous city marketing: A case study of Xuyi County, China. Planning Theory 12(4): 406-24.

Mei, Weiqiang 梅伟强 (2002) 从侨情调查看江门五邑侨乡特色 (Identifying the characteristics of Jiangmen Wuyi from the study of a recently published survey of Overseas Chinese), 2 December, http://www.southen.com/news/gdnews/hotspot/sylhsy/sylh/lhqiaoqing/20021202 0868.htm, accessed 18 April 2016. 
Mei, Weiqiang 梅伟强 and Zhang, Guoxiong 张国雄 (eds) (2001) 五邑华侨华人史 (The History of Wuyi Overseas Chinese). Guangzhou: 广东高等教育出版社 (Guangdong Gaodeng Jiaoyu Chubanshe).

Moore, Henrietta L. and Todd Sanders (eds) (2001) Magical Interpretations, Material Realities: Modernity, Witchcraft, and the Occult in Postcolonial Africa. London: Routledge.

Nyiri, Pal (2006) Scenic Spots: Chinese Tourism, the State, and Cultural Authority. Seattle, WA: University of Washington Press.

Oakes, Tim (1998) Tourism and Modernity in China. London: Routledge.

Oakes, Timothy S. (1993) The cultural space of modernity: Ethnic tourism and place identity in China. Environment and Planning D: Society and Space 11(1), 47-66.

Oakes, Tim (2012) Heritage as improvement: Cultural display and contested governance in rural China. Modern China 39(4): 380-407.

Oakes, Tim (2016) Villagizing the city: Turning rural ethnic heritage into urban modernity in southwest China. International Journal of Heritage Studies 22 (10): $751-65$.

Peirce, Charles (1995) Logic as semiotic: The theory of signs. In: Philosophical Writings of Peirce, selected and edited with an introduction by Buchler, Justua. New York: Dover Publications, 1995: 95-119.

Prakash, Gyan (1999) Another Reason: Science and the Imagination of Modern India. Princeton, N.J. : Princeton University Press.

Ren, Xuefei. (2014) The political economy of urban ruins: Redeveloping Shanghai. International Journal of Urban and Regional Research 38 (3): 1081-91.

Saler, Michael (2006) Modernity and enchantment: A historiographic review. The American Historical Review 111(3): 692-716.

Schein, Louisa (1989) The dynamics of cultural revival among the Miao in Guizhou. In: Chiao, Chien and Tapp, Nicholars (eds) Ethnicity and Ethnic Groups in China. Hong Kong: Chinese University of Hong Kong, 99-212.

Shih, Chih-yu (2002) Negotiating Ethnicity in China: Citizenship as A Response to the State. London: Routledge.

Siu, Helen (1989) Recycling rituals: politics and popular culture in contemporary rural China. In: Perry, Link, Madsen, Richard and Pickowicz, Paul G. (eds) 
Unofficial China: Popular Culture and Thought in the People's Republic of China. Boulder, CO: Westview Press, 121-37.

Standen, Naomi and Bennett, Gwen (2014). Difficult histories: Changing presentations of the Liao in regional museums in the People's Republic of China over three decades. Modern Asian Studies 48(6):1519-1565

Su, Xiaobo and Teo, Peggy (2009) The Politics of Heritage Tourism in China: A View from Lijiang. London: Routledge.

Svensson, Marina (2006) In the Ancestors' Shadow: Cultural Heritage Contestations in Chinese Villages. Working Paper No. 17, Centre for East and South-East Asian Studies, Lund University.

Tian, Wei 田伟 (2015) 江门首发侨务“十三五”蓝图 吹响侨都建设号角(Jiangmen released the 13th Five-year Plan for Overseas Chinese Affairs, blowing the trumpet for building Jiangmen into China's capital of Overseas Chinese), 人民网 (People's Net), 13 October, http://www.chinaqw.com/gqqj/2015/1013/66812.shtml, access 22 April 2016.

Tuan, Yi-Fu and Hoelscher, Steven (1997) Disneyland: Its place in world culture. In: Marling, Karal Ann (ed.) Designing Disney's Theme Parks: The Architecture of Reassurance. Paris: Flammarion, 192-98.

Varutti, Marzia (2011) Miniatures of the nation: Ethnic minority figurines, mannequins and diorama in Chinese museums. Museum and Society 9 (1): 1-16.

Visser, Robin (2010) Cities Surround the Countryside: Urban Aesthetics in Postsocialist China. Durham, NC: Duke University Press.

Wang, Meiqin (2015) Advertising the Chinese dream: Urban billboards and $\mathrm{Ni}$ Weihua's documentary photography. China Information 29 (2): 176-201.

Weber, Max (1946) Science as a vocation. In: From Max Weber: Essays in Sociology. Trans., edited and with an introduction By Gerth, H. H. and Mills, C. Wright. New York: Oxford University Press, 129-56.

Wills, Garry (2014) Making Make-Believe Real: Politics as Theatre in Shakespeare's Time. New Haven: Yale University Press.

Wu, Fulong (2007) Beyond gradualism: China's urban revolution and emerging cities. In: Wu, Fulong (ed) (2007) China's Emerging Cities: The Making of New Urbanism. London and New York: Routledge, 3-25. 
五邑华侨博物馆：游走史间 思接当年 (Wuyi Overseas Chinese Museum: In dialogue with the past, thinking about the Future), 江门日报 (Jiangmen Daily) 23 November, 2005 http://www.chinaqw.com/news/2005/1123/68/6509.shtml, accessed 7 June 2015.

Xing, Liyu 邢利宇 (2004) 中国江门举办侨乡华人嘉年华 两千华人欢聚一堂 (Jiangmen hosting Overseas Chinese Carnival, two thousand guests happily gathering together), 中国新闻网 (China News Net), 18 October, http://www.chinanews.com/news/2004/2004-10-18/26/495446.shtml, accessed 7 June 2015.

Yan, Haiming (2015) World Heritage as discourse: Knowledge, discipline and dissonance in Fujian Tulou sites. International Journal of Heritage Studies 21(1): 65-80.

Yang, Li (2011) Ethnic tourism and cultural representation. Annuals of Tourism Research 38(2): 561-85.

Yang, Minhui 杨慧敏 (2009) 五邑华博馆: 侨乡地标 城市之魂 (Wuyi Overseas Chinese Museum: the landmark of a hometown of Overseas Chinese and the spirit of the city), 江门日报(Jiangmen Daily), 7 December, Issue 7373: A03, http://dzb.jmrb.com:8080/jmrb/html/2009-12/07/content_143281.htm, accessed 10 June 2015.

Yaogongchong zld 摇滚虫 zld (2011) 江门五邑华侨博物馆带出的问题(Comments on the Problems of Jiangmen Wuyi Overseas Chinese Museum), 7 January, http://wz.wen.oeeee.com/Content/67350.htm, accessed 7 June 2015.

Zhang, Li and Zhao, Xiaobin (2009) City branding and the Olympic effect: A case study of Beijing. Cities 26(5): 245-54.

Zhang, Maosheng 张茂盛 Ou, Jingchang 区景常 and Chen, Sumin 陈素敏 （2012） 明年嘉年华如何办? 市委宣传部向各方问计 (How to run next year's Overseas Chinese Carnival? The Propaganda Department consulted specialists), 江门日报 (Jiangmen Daily), 28 November, http://www.jiangmen.gov.cn/zwgk/ztbd/2013jnh/201211/t20121128_353634.ht $\underline{\mathrm{ml}}$, accessed 29 November 2016. 
Zhang, Yingchun and Wu, Zongjie (2016): The reproduction of heritage in a Chinese village: Whose heritage, whose pasts?, International Journal of Heritage Studies 22(3): $228-41$.

Zhao, Yawen (2015) China's leading historical and cultural city: Branding Dali City through public-private partnerships in Bai architecture revitalization. Cities 49: $106-12$.

Zhu, Yujie (2012) When the global meets the local in tourism - Cultural performances in Lijiang as case studies. Journal of China Tourism Research 8(3): $302-19$. 